Tersedia online di:http://ejournal-balitbang.kkp.go.id/index.php/jkpi
e-mail:jkpi.puslitbangkan@gmail.com
JURNAL KEBIJAKANPERIKANANINDONESIA
Volume 10 Nomor 2 November 2018
p-ISSN: 1979-6366
e-ISSN: 2502-6550
Nomor Akreditasi Kementerian RISTEKDIKTI: 21/E/KPT/2018

\title{
KELAYAKAN UMUM DAN TEKNIS PENGEMBANGAN KAWASAN SENTRA INDUSTRI BUDIDAYA IKAN NILA DI KABUPATEN MUSI RAWAS
}

\section{THE GENERAL AND TECHNICAL FEASIBILITY IN THE DEVELOPMENT OF THE CENTRE INDUSTRIAL AREAS OF TILAPIA FARMING IN MUSI RAWAS REGENCY}

\author{
Raden Roro Sri Pudji Sinarni Dewi ${ }^{\star 1}$, Estu Nugroho' ${ }^{1}$, Fatriyandi Nur Priyatna ${ }^{2}$, Sugiyono $^{3}$ \\ ${ }^{1}$ Pusat Riset Perikanan, Gedung Balitbang KP II. JI. Pasir Putih II, Ancol Timur, Jakarta Utara, Indonesia \\ ${ }^{2}$ Balai Besar Sosial Ekonomi Kelautan dan Perikanan, Gedung Balitbang KP I. JI. Pasir Putih II, Ancol Timur, Jakarta Utara, Indonesia \\ ${ }^{3}$ Balai Besar Pengolahan Produk dan Bioteknologi Hasil Perikanan, Jalan KS Tubun, Petamburan VI, Slipi, Jakarta Pusat, Indonesia \\ Teregistrasi I tanggal: 24 Januari 2018; Diterima setelah perbaikan tanggal: 21 Agustus 2018; \\ Disetujui terbit tanggal: 27 Agustus 2018
}

\begin{abstract}
ABSTRAK
Penetapan kawasan industri budidaya ikan nila merupakan salah satu sarana untuk mengembangkan industri yang berwawasan lingkungan serta memberikan kemudahan dan daya tarik untuk berinvestasi. Kabupaten Musi Rawas sebagai produsen ikan nila terbesar di Indonesia berpotensi untuk dikembangkan sebagai kawasan sentra industri budidaya ikan nila. Tujuan penelitian ini adalah untuk menentukan kesenjangan kondisi eksisting dan kondisi ideal pada aspek kelayakan umum dan teknis Kabupaten Musi Rawas yang berpotensi untuk dikembangkan sebagai kawasan sentra industri budidaya ikan nila. Diharapkan agar kawasan industri yang dikembangkan sesuai dengan tata ruang, meminimalisasi dampak negatif dan mengembangkan dampak positif terhadap lingkungan hidup, berdaya guna dan berhasil guna, sehingga pada gilirannya mampu menarik peluang investasi bagi pengembangan industri di daerah. Aspek yang dianalisis meliputi aspek kelayakan umum dan kelayakan teknis. Aspek kelayakan umum meliputi: dimensi infrastruktur, masyarakat dan bisnis, sumberdaya, kelembagaan, teknologi, kebijakan, dan pemasaran. Aspek kelayakan teknis meliputi pembenihan, pembesaran di kolam air deras, pembesaran di kolam air tenang, dan pengolahan produk perikanan. Berdasarkan analisis kesenjangan, Kabupaten Musi Rawas termasuk dalam kategori SEDANG, yaitu secara umum dan teknis Kabupaten Musi Rawas memiliki beberapa kriteria sebagai sebuah kawasan sentra industri budidaya ikan nila namun masih diperlukan adanya pengembangan pada beberapa hal seperti: optimalisasi balai benih ikan, penerapan teknologi tepat guna dan peningkatan pemasaran produk hasil perikanan didukung kebijakan yang menfasilitasi kebutuhan akan meningkatkan kelayakan sebagai lokasi sentra industri budidaya ikan nila. Rekomendasi kebijakan yang perlu diambil oleh pemerintah pusat dan daerah untuk pengembangan kawasan sentra industri di Kabupaten Musi Rawas diantaranya melalui optimalisasi peranan balai benih ikan, transfer teknologi tepat guna, diversifikasi produk olahan, penguatan potensi pasar melalui promosi, penguatan kelembagaan produksi, pengolah dan pemasaran hasil perikanan, dan resolusi konflik pemanfaatan dan pengelolaan air irigasi untuk kebutuhan pertanian dan perikanan.
\end{abstract}

Kata Kunci: Sentra industri; ikan nila; Kabupaten Musi Rawas

\begin{abstract}
Determination of area for Tilapia culture will be meaningful for business development, ecofriendly, sustainability, and attractiveness by the investor. Musi Rawas Regency as the largest tilapia producer in Indonesia is highly potential areas to be developed as a center of tilapia farming industry. The purpose of this study is to determine the general and technical feasibility condition of Musi Rawas Regency which will be developed as a center of tilapia farming industry. It is expected that industrial zones developed in accordance with the spatial plan, will minimize the negative impact to the environment, efficient and effective so that the ability to attract opportunities for industrial development in the region. Aspects analyzed for general eligibility were infrastructure,
\end{abstract}


society and business, resources, institutions, technologies, policies, and market. The aspect of the techniques is the feasibility of hatchery, farmings in flowing water pond, stagnant water ponds, and fish product processing. Based on the gap analysis, Musi Rawas Regency is belonged to the moderate category, in which generally and technically Musi Rawas Regency already has several criteria as a center of tilapia industry but still a need for development on several items such as optimization of the hatchery, application of appropriate technology and enhancement of marketing for fishery products supported by the facilitating policy. Required policy recommendations to be implemented by the central and regional governments for the development of industrial centers in Musi Rawas Regency are optimization of fish seed center, transfer of appropriate technology, diversification of fish products, strengthening of the market potential through promotion, strengthening of production institutions, fish product processing and marketing, and resolution of utilization and management of irrigation water for agricultural and fishery needs.

\section{Keywords: Industrial center; tilapi; Musi Rawas Regency}

\section{PENDAHULUAN}

Percepatan pembangunan industri perikanan nasional ditujukan untuk meningkatkan kesejahteraan masyarakat baik nelayan, pembudidaya, pengolah maupun pemasar hasil perikanan, meningkatkan penyerapan tenaga kerja dan meningkatkan devisa negara. Instruksi Presiden Republik Indonesia Nomor 7 Tahun 2016 tentang Percepatan Pembangunan Industri Perikanan Nasional mengamanahkan kepada Kementerian Kelautan dan Perikanan (KKP) untuk menyusun roadmap industri perikanan nasional, penetapan lokasi, dan masterplan kawasan industri perikanan nasional sebagai proyek strategis nasional (KKP, 2017). Peraturan Presiden Nomor 3 Tahun 2017 tentang Rencana Aksi Percepatan Pembangunan Industri Perikanan Nasional lebih rinci mengatur agar kementerian/lembaga terkait melakukan perencanaan, pelaksanaan, pemantauan, serta evaluasi Rencana Aksi Pembangunan Industri Perikanan Nasional; dan mengamanahkan kepada pemerintah daerah untuk menyusun Rencana Aksi Daerah terkait Pembangunan Industri Perikanan (ILB, 2017a).

Penetapan kawasan industri merupakan salah satu sarana untuk mengembangkan industri yang berwawasan lingkungan serta memberikan kemudahan dan daya tarik untuk berinvestasi. Hal ini sejalan dengan amanat dalam UU No. 5 Tahun 1984 tentang Perindustrian bahwa upaya untuk mendorong pembangunan industri perlu dilakukan melalui pembangunan lokasi industri yaitu berupa kawasan industri (ILB, 2017b). Pembangunan suatu kawasan industri memerlukan persyaratan-peryaratan tertentu yaitu harus memenuhi kaidah-kaidah kelayakan teknis, ekonomis, dan finansial; disamping dukungan peraturan dan kebijakan pemerintah yang kondusif.

Indonesia merupakan negara pengekspor fillet ikan nila terbesar kedua setelah Cina. Pada semester pertama tahun 2014, Indonesia menyuplai lebih dari $22 \%$ (4.840 ton dari 22.000 ton) kebutuhan fillet ikan nila beku ke pasaran internasional (FAO, 2017). Upaya peningkatan produksi ikan nila sebagai komoditas ekspor dan domestik perlu diimbangi dengan dibentuknya kawasan sentra industri. Pembangunan dan pengembangan sentra industri budidaya ikan nila mengacu kepada Peraturan Menteri Perindustrian Republik Indonesia Nomor: 35/M-IND/ PER/3/2010 tentang Pedoman Teknis Kawasan Industri (ILB, 2017c).

Industri dalam perikanan budidaya mempunyai tujuan untuk mempersiapkan produk yang digunakan sebagai bahan baku untuk keperluan industrialisasi. Keberhasilan industrialisasi sangat bergantung pada kinerja hulu (produksi benih dan budidaya) dan hilir (pasca panen dan pemasaran) serta tingkat efisiensi teknologi yang digunakan. Keunggulan nilai didapatkan dengan dihasilkannya produk bernilai tinggi sesuai dengan keinginan konsumen, sedangkan keunggulan produktivitas didapatkan melalui volume produksi yang tinggi dengan biaya proses yang rendah. Hal ini dikarenakan bahwa daya saing identik dengan konsep efisiensi (Kurniaty et al. 2012). Nugroho et al. (2012) menyebutkan bahwa terdapat tiga pilar utama dalam industri budidaya ikan yaitu kualitas benih, efisiensi penggunaan teknologi secara massal dan pengolahan yang berkesinambungan. Keberadaan pilar industri beserta pendukungnya perlu dikaji dalam upaya pengembangan sentra industri perikanan budidaya ikan nila di Kabupaten Musi Rawas. Produksi budidaya ikan nila di Kabupaten Musi Rawas menduduki peringkat pertama dalam kontribusi terhadap produksi perikanan ikan nila di Indonesia. Tercatat produksi ikan nila pada tahun 2016 mencapai 45 ribu ton (Dinas Perikanan Kabupaten Musi Rawas, 2016). Sebagian besar produksi hasil perikanan di Kabupaten Musi Rawas dipasarkan ke luar daerah yaitu sekitar $82,29 \%$ sedangkan sisanya dikonsumsi masyarakat lokal (Nugroho et al., 2012). 
Tujuan penelitian ini yaitu untuk menentukan kesenjangan (gap analysis) antara kondisi eksisting dengan kondisi yang diharapkan (ideal) pada aspek kelayakan umum dan teknis di Kabupaten Musi Rawas sebagai sebuah kawasan yang berpotensi untuk dikembangkan sebagai kawasan sentra industri budidaya ikan nila. Diharapkan kawasan industri yang dikembangkan sesuai dengan tata ruang, meminimalisasi dampak negatif dan mengembangkan dampak positif terhadap lingkungan hidup, berdaya guna dan berhasil guna, sehingga pada gilirannya mampu menarik peluang investasi bagi pengembangan industri di Kabupaten Musi Rawas.

Kegiatan penelitian dilaksanakan pada bulan Agustus - Desember tahun 2017. Data yang diambil dari kegiatan penelitian terdiri dari data primer dan data sekunder. Data primer diperoleh melalui wawancara langsung dengan responden (pengambil kebijakan/SKPD terkait, pelaku usaha atau stakeholder lainnya) dengan di pandu oleh kuesioner terstruktur serta focus group discussion. Pengumpulan data sekunder dilakukan dengan cara mencatat dan mempelajari dokumen tertulis (Peraturan daerah Kabupaten Musi Rawas terkait tentang RTRW, RPJMD, RPIJM kawasan minapolitan, masterplan minapolitan) dan laporan-laporan. Metode pengambilan responden dilakukan dengan metodeter pilih (Purposive sampling) yang terdiridari SKPD, UPR, pembudidaya, pengolah, dan pedagang. Menurut Sugiyono (2009), metode purposive sampling adalah metode pengambilan sampel sumber data dengan tujuan dan pertimbangan tertentu. Analisis untuk melihat gambaran kelayakan aspek umum dan aspek teknis dilakukan dengan menggunakan metode analisis deskriptif tabulatif. Penilaian kelayakan sentra industry perikanan budidaya yang berbasis komoditas menggunakan analisis nilai kesenjangan/gapanalysis. Pengukuran nilai kesenjangan digunakan untuk mengetahui setiap atribut yang mempengaruhi pengembangan suatu lokasi menjadi sentra industri. Analisis kesenjangan digunakan untuk membandingkan kondisi umum dan teknis budidaya ikan nila di Kabupaten Musi Rawas pada saat ini dengan kondisi sentra industri yang dijadikan acuan (Sari et al., 2014). Kondisi sentra industri yang dijadikan acuan merupakan target untuk mengembangkan Kabupaten Musi Rawas sebagai lokasi sentra industri budidaya ikan nila. Posisi gap/ kesenjangan secara kuantitatif ditunjukkan dengan indeks komposit. Nilai indeks komposit hasil hitungan masing-masing atribut tersebut berkisar antara 0 (keadaan terburuk) dan 1 (keadaan terbaik). Nilai indeks komposit 0- 0,30 menunjukkan kategori rendah (kesenjangan Antara kondisi eksisting dengan ideal masih tinggi), 0,31-0,60 kategori sedang (kesenjangan
Antara kondisi eksisting dengan ideal berada pada posisi sedang), dan 0,61 - 1 kategori tinggi (kesenjangan Antara kondisi eksisting dengan ideal berada pada posisi rendah). Indeks komposit dalam kajian ini terdiri dari berbagai indeks komposit, yaitu indeks kompositas pekumum (infrastruktur, masyarakat dan bisnis, sumberdaya, kelembagaan, teknologi, kebijakan, dan pemasaran) dan indeks kompositas pekteknis (pembenihan, pembesaran di kolam air deras, pembesaran di kolam air tenang, dan pengolahan produk perikanan). Indeks komposit dibentuk berdasarkan suatu himpunan rerata indicator masalah.

\section{BAHASAN \\ Kelayakan Umum Kabupaten Musi Rawas sebagai Lokasi Sentra Industri Budidaya Ikan Nila}

Nilai indeks komposit sebagai hasil dari analisis kesenjangan menunjukkan kelayakan umum Kabupaten Musi Rawas sebagai lokasi sentra industri budidaya ikan nila sebesar 0,57 atau masuk dalam kategori SEDANG (Gambar 1). Nilai ini menggambarkan bahwa secara umum, Kabupaten Musi Rawas telah memenuhi beberapa persyaratan sebagai suatu kawasan sentra industri budidaya ikan nila terutama pada aspek pemasaran, masyarakat dan bisnis, serta infrastruktur. Namun untuk mencapai kondisi ideal diperlukan pengembangan pada beberapa aspek seperti kebijakan, teknologi, kelembagaan dan sumberdaya. Nilai indeks komposit tertinggi yaitu terdapat pada dimensi pemasaran, sementara nilai terendah ada pada dimensi kebijakan. Secara umum hal ini menunjukkan bahwa potensi pasar yang tersedia untuk komoditas ikan nila sangatlah besar, namun masih perlu lebih jauh didukung dengan tersedianya kebijakan perikanan yang dapat mendorong upaya terbentuknya kawasan sentra industri budidaya ikan nila.

Penilaian dimensi infrastruktur meliputi: kondisi jalan, ketersediaan air untuk budidaya, ketersediaan air untuk konsumsi, saluran irigasi, cold storage, pabrik es, Balai Benih Ikan (BBI), Hatchery Skala Rumah Tangga (HSRT), pabrik pakan, unit pengolahan ikan, pasokan listrik, saluran komunikasi, bahan bakar minyak (BBM), penjual sarana produksi, fasilitas \& sarana transportasi, dan bangunan pasar. Nilai tertinggi dari kondisi eksisting dimensi infrastruktur di Kabupaten Musi Rawas adalah saluran komunikasi, pasokan listrik dan fasilitas transportasi darat untuk pengiriman ikan. Sementara nilai komposit terendah pada parameter ketersediaan coldstorage dan pabrik pakan. Cold storage tidak tersedia karena orientasi pasar dari hasil budidaya ikan nila di Kabupaten Musi Rawas masih pada penjualan dalam bentuk hidup 
untuk memenuhi kebutuhan di beberapa provinsi di Pulau Sumatera. Sementara pabrik pakan sampai saat ini masih belum tersedia di Kabupaten Musi
Rawas. Kebutuhan pakan komersial untuk budidaya ikan nila di Kabupaten Musi Rawas masih diambil dari Pulau Jawa.

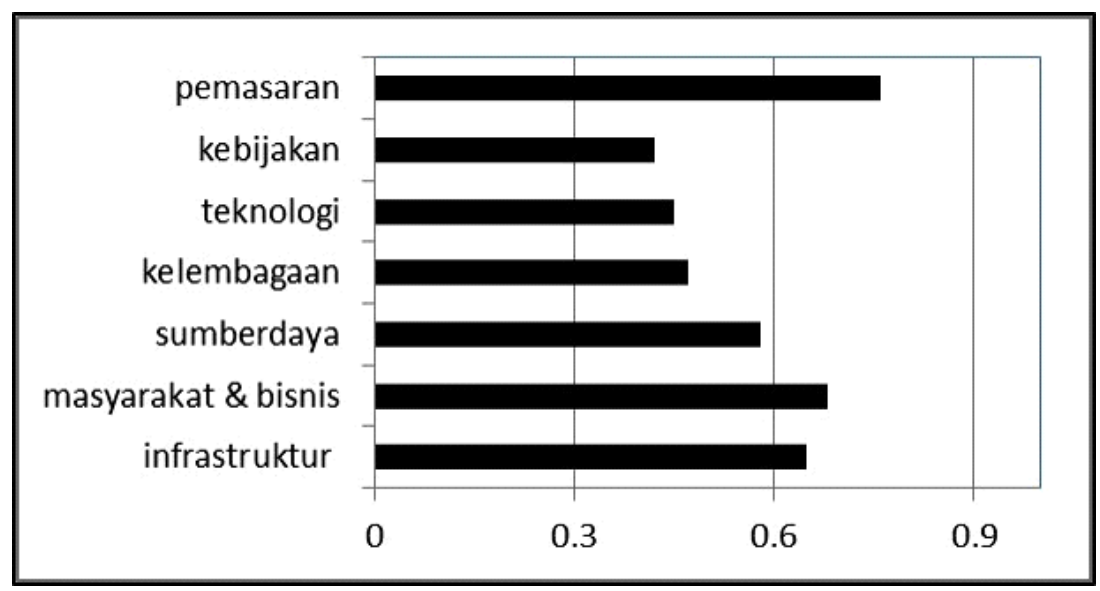

Gambar 1. Indeks komposit kelayakan umum Kabupaten Musi Rawas sebagai lokasi sentra industri budidaya ikan nila (rendah : 0-0,3; sedang: 0,31-0,6; tinggi: 0,61-1).

Figure 1. Composite index of general feasibility of Musi Rawas Regency as the location of tilapia industrial center (low: 0-0,3; moderate: 0,31-0,6; height: 0,6-1).

Penilaian dimensi masyarakat dan bisnis meliputi : komposisi masyarakat, peran perempuan, pelaku pembudidaya, pelaku pemasaran, pelaku pengolah hasil perikanan, buruh, penyedia jasa transportasi distribusi, penyedia sarana produksi perikanan, mata pencaharian, investasi usaha budidaya, keuntungan usaha, dan prospek pasar. Nilai indeks komposit tertinggi adalah pada parameter keuntungan usaha dan prospek pasar. Kedua nilai komposit tertinggi tersebut memberikan gambaran bahwa secara bisnis lokasi sentra industri budidaya ikan nila di Kabupaten Musi Rawas sangatlah potensial. Prospek pasar saat ini masih berkisar pada penjualan ikan hidup untuk konsumsi. Potensi pasar masih sangat terbuka untuk penjualan ikan hidup karena saat ini Kabupaten Musi Rawas masih belum dapat memenuhi kebutuhan sepanjang tahun ikan nila konsumsi di luar kabupaten. Potensi pasar untuk pembenihan juga masih sangat terbuka karena kecenderungan semakin bertambahnya usaha budidaya pembesaran ikan nila, utamanya pada jenis budidaya kolam air tenang yang membutuhkan ketersediaan benih yang cukup dan berkualitas. Parameter penduduk lokal yang berperan sebagai pembudidaya, pemasaran, pengolah dan buruh pada kawasan sentra budidaya perikanan nila merupakan parameter yang memiliki nilai indeks komposit terendah. Hal ini menandakan bahwa masih sedikit penduduk lokal yang terlibat dalam kegiatan budidaya ikan nila dan lebih banyak didominasi oleh penduduk yang berasal dari luar daerah.

Penilaian dimensi sumberdaya meliputi : ketersediaan sumberdaya alam (SDA) dan kemampuan sumberdaya manusia (SDM). Kemampuan SDM di Kabupaten Musi Rawas masuk dalam kategori SEDANG untuk pengembangan sentra industri budidaya ikan nila, namun demikian masih dapat ditingkatkan lebih jauh dengan dilakukan bimbingan teknis dari sumber-sumber pengetahuan dan teknologi, terutama budidaya ikan nila. Menurut Andriyaniet al. (2011), pengembangan SDM produktif perlu meningkatkan pengetahuan melalui pelatihanpelatihan pembudidayaan ikan dengan memperhatikan teknologi peralatan, bahan baku yang dapat meningkatkan mutu dan modal yang dibutuhkan dalam pembudidayaan ikan dan target pasar.Sementara parameter sumber daya alam masuk dalam kategori SEDANG. Masalah utama parameter sumber daya adalah terkait ketersediaan dan kualitas air untuk budidaya. Ketersediaan air untuk budidaya masih menjadi masalah karena masih adanya potensi konflik penggunaan akibat harus berbagi dengan pertanian dalam pemanfaatannya. Kualitas air juga dirasakan semakin menurun, khususnya bagi budidaya ikan nila pada jenis kolam air deras. Kondisi air saat ini cenderung keruh, terutama saat musim penghujan.

Penilaian dimensi kelembagaan meliputi bentuk kelembagaan mendukung program sentra industri, kelembagaan resolusi konflik, dan bentuk kelembagaan dalam mengelola sumberdaya perikanan. Nilai komposit tertinggi tercatat pada kelembagaan yang telah ada dalam upaya mendukung program sentra industri. Nilai komposit terendah tercatat pada kelembagaan pengelola 
sumber daya perikanan. Secara umum hal ini disebabkan belum adanya kelembagaan pengelola sumber daya perikanan yang bersifat partisipatif dan kolaboratif antara masyarakat dan pemerintah. Peran sentral dalam pengelolaan sumber daya perikanan masih berada pada Pemda Kabupaten Musi Rawas.

Penilaian dimensi teknologi meliputi: teknologi budidaya, teknologi handling dan pasca panen, dan teknologi transportasi. Masyarakat pembudidaya di Kabupaten Musi Rawas lebih menguasai tentang teknologi budidaya dibanding kedua teknologi lainnya. Pemahaman teknologi budidaya tergolong tinggi. Sementara nilai indeks komposit terendah pada parameter teknologi handling dan pasca panen. Hal ini disebabkan karena orientasi usaha budidaya ikan nila masih untuk memenuhi kebutuhan pasar ikan hidup yang masih tinggi. Tingginya permintaan untuk ikan hidup menyebabkan usaha pengolahan dan pasca panen menjadi kurang berkembang.

Penilaian dimensi kebijakan meliputi : rencana tata ruang wilayah (RTRW), masterplan, rencana pembangunan jangka menengah daerah (RPJMD), dan peraturan terkait lainnya. Dimensi kebijakan di Kabupaten Musi Rawas masuk dalam kategori SEDANG. Nilai indeks komposit tertinggi disebabkan karena telah tersedianya dokumen tentang tata ruang wilayah yang telah mempertimbangkan lokasi-lokasi sentra perikanan budidaya. Kebijakan dan regulasi pemerintah daerah masih rendah diakibatkan karena permasalahan kewenangan pengaturan yang telah ditarik ke pemerintah provinsi.Muhammad (2011) mengemukakan bahwa kebijakan perikanan diperlukan untuk menciptakan penguatan aturan dalam mengatasi kepemilikan bersama pada sumberdaya perikanan sehingga pengelolaan stok ikan dan pemanfaatannya dapat diatur secara adil dan merata.Implementasi otonomi daerah seharusnya dapat meningkatkan kualitas kebijakan perikanan dalam pengelolaan sumberdaya ikan secara berkelanjutan. Kebijakan perikanan tersebut dapat direalisasikan melalui pemeliharaan, pertahanan, dan peningkatan daya dukung sektor kelautan dan perikanan yang berkelanjutan. Selain hal tersebut, daerah juga harus meningkatkan upaya penegakkan hukum, peningkatan mutu serta diversifikasi produk perikanan. Dalam mewujudkannya, diperlukan koordinasi yang baik antara pemerintah pusat dan daerah agar implementasi kebijakan perikanan dapat berjalan secara sinergis (Zulbainarni, 2012).
Penilaian dimensi pemasaran meliputi : pemasaran dan akses transportasi pemasaran. Nilai indeks komposit dimensi pemasaran masuk dalam kategori TINGGI. Tercatat bahwa akses transportasi dan jaringan pemasaran baik di dalam maupun luar kabupaten sudah tersedia dengan baik. Satu-satunya akses dan jaringan pemasaran yang belum terbentuk adalah pada akses pasar ekspor. Tingginya permintaan ikan nila segar dari wilayah di sekitar Kabupaten Musi Rawas menyebabkan belum berkembangnya usaha untuk memenuhi kebutuhan pasar ekspor. Namun perlu ada upaya untuk mengantisipasi lesunya pasar lokal, diantaranya melalui kerjasama antara pihak pemerintah dan swasta untuk memulai membuka usaha pengolahan produk perikanan agar produk ikan nila yang dihasilkan dapat memenuhi kriteria kebutuhan pasar ekpor. Dimensi pemasaran ini juga memberikan gambaran potensi pasar untuk komoditas ikan nila masih sangat tinggi. Menurut Nainggolan et al. (2010), keunggulan pemasaran adalah harus dapat meningkatkan pelayanan dalam penjualannya, karena dapat menjadi salah satu nilai pembeda dengan pesaing.

\section{Kelayakan Teknis Kabupaten Musi Rawas sebagai Lokasi Sentra Industri Budidaya Ikan Nila}

Pembangunan subsektor perikanan dalam sistem agribisnis adalah membangun dan mengembangkan subsistem industri hulu perikanan (perbenihan, industri peralatan penangkapan ikan, industri pakan ikan), subsistem budi daya atau penangkapan ikan dan penanganan pasca penangkapan, subsistem pengolahan hasil perikanan dan perdagangan, subsistem jasa penunjang (terutama kegiatan penelitian dan pengembangan) secara terintegrasi dalam suatu sistem, baik sistem nilai maupun pengelolaannya (Saragih, 2010). Pada penelitian ini, kelayakan teknis lokasi sentra industri perikanan budidaya ikan nila tersusun berdasarkan dimensi sosial dan ekonomi, teknologi (pembenihan, pembesaran, pengolahan produk), serta sumberdaya. Berdasarkan hasil analisis kesenjangan bahwa nilai indeks komposit kelayakan teknis Kabupaten Musi Rawas sebagai lokasi sentra industri perikanan budidaya nila adalah sebesar 0,59 atau masuk dalam kategori SEDANG. Nilai ini menunjukkan, bahwa secara teknis budidaya ikan nila menguntungkan, namun masih perlu ditingkatkan efisiensinya terutama pada tahap pembenihan, pembesaran di kolam air deras dan pengolahan hasil perikanan. 


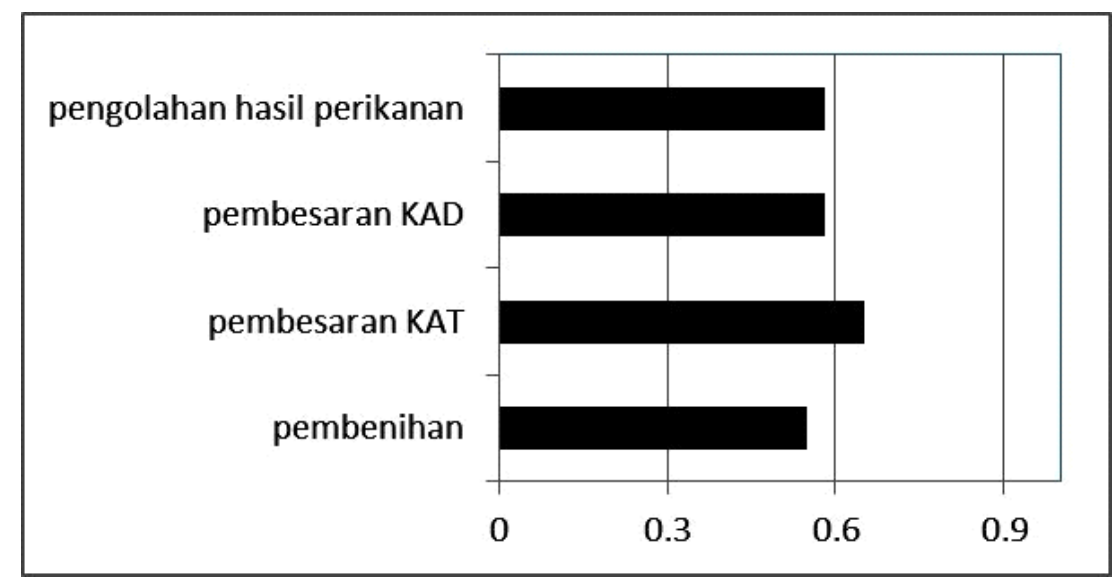

Gambar 2. Indeks komposit kelayakan teknis Kabupaten Musi Rawas sebagai lokasi sentra industri budidaya ikan nila (rendah : 0-0,3; sedang: 0,31-0,6; tinggi: 0,61-1).

Figure 2. Composite index of technical feasibility of Musi Rawas Regency as the location of tilapia industrial center (low: 0-0,3; moderate: 0,31-0,6; height: 0,61-1).

Secara ekonomi, unit usaha pembenihan memiliki keuntungan ekonomi yang besar. Nilai rata-rata $\mathrm{RC}$ ratio yang diperoleh untuk usaha pembenihan ikan nila sebesar 4,27. Dimensi teknologi yang rendah disebabkan masih bersifat ekstensifikasi dengan efisiensi produksi benih yang masih sedang. Penyebab dari hal ini adalah terletak pada masalah ketersediaan jumlah kualitas induk yang kurang baik.

Usaha budidaya pembesaran di kolam air tenang memberikan keuntungan ekonomi yang besar. Hal ini terlihat dari nilai $\mathrm{RC}$ ratio yang rata-rata sebesar 1,43. Masalah utama yang ada pada pembesaran ikan nila sistem kolam air tenang (KAT) adalah penggunaan benih yang kurang berkualitas. Tercatat bahwa nilai FCR budidaya ikan nila berkisar antara 1,4-1,8. Selain itu faktor kualitas air juga dapat menjadi penyebabnya. Penggunaan air irigasi langsung tanpa melakukan pengontrolan tidak dapat menjamin ikan mendapatkan lingkungan yang baik untuk pertumbuhannya.

Usaha budidaya pembesaran nila pada kolam air deras (KAD) termasuk dalam skala teknologi bersifat intensif. Nilai FCR di kolam arus deras sampai mencapai nilai 2 menunjukkan adanya inefisiensi dalam pemanfaatan makanan yang diberikan. Pembudidaya kolam air deras umumnya juga memiliki usaha lain sebagai distributor pakan, pedagang pengumpul dan juga pembenihan. Sehingga hulu hilir usaha dikuasai oleh satu pihak saja.

Pengolahan hasil perikanan dari komoditas ikan nila belum banyak berkembang di Kabupaten Musi Rawas. Pengolahan hasil perikanan yang sudah berkembang berbahan baku ikan lele. Kelayakan teknis dari usaha pengolahan ikan nila di Kabupaten
Musi Rawas lebih bersifat pada estimasi potensi pengembangan usaha pengolahan produk ikan nila. Ketersediaan bahan baku untuk nila sebenarnya baik, mengingat sering kali nila terjadi over supply yang menyebabkan harga jatuh. Usaha pengolahan dengan prinsip nir limbah menjadi salah satu alternatif untuk menambah nilai pada komoditas ikan nila.

\section{KESIMPULAN DAN REKOMENDASI Kesimpulan}

Kabupaten Musi Rawas memenuhi beberapa kriteria sebagai sebuah kawasan yang berpotensi untuk dikembangkan sebagai sentra industri budidaya ikan nila. Pada aspek kelayakan umum, kriteria yang telah memenuhi syarat sebagai sebuah kawasan industri antara lain: pemasaran, masyarakat dan bisnis, serta infrastruktur. Adapun kriteria kelayakan umum yang masih perlu ditingkatkan adalah kebijakan, teknologi, kelembagaan, dan sumberdaya. Pada aspek kelayakan teknis, kegiatan pembesaran ikan di kolam air tenang cukup efektif dan efisien. Efisiensi yang masih perlu ditingkatkan antara lain pada kegiatan pembenihan, pembesaran di kolam air deras, dan pengolahan produk perikanan. Optimalisasi balai benih ikan, penerapan teknologi tepat guna dan peningkatan pemasaran produk hasil perikanan didukung kebijakan yang menfasilitasi kebutuhan pada aspek teknis, akan meningkatkan kelayakan Kabupaten Musi Rawas sebagai kawasan sentra industri budidaya ikan nila.

\section{Rekomendasi}

Optimalisasi Peranan BBI dalam menghasilkan benih unggul, dilakukan melalui koordinasi antara pemerintah pusat (Kementerian Kelautan dan 
Perikanan) dan pemerintah daerah (Dinas Perikanan Kabupaten Musi Rawas) untuk melakukan revitalisasi sarana dan prasarana serta induk unggul serta memfasilitasi bimbingan teknis budidaya terhadap operator $\mathrm{BBI}$ dan pelaku usaha rakyat (UPR). Transfer teknologi tepat guna dalam usaha budidaya ikan nila, dilakukan melalui koordinasi antara pemerintah pusat dan daerah untuk membuat program dempond (demonstration pond) dan membuat program hilirisasi hasil riset pada skala lapang. Diversifikasi produk olahan, melalui koordinasi antara pemerintah pusat dan daerah untuk mengembangkan mekanisasi pengolahan hasil yang tepat guna, membuat program pemberian bantuan sarana dan prasarana pengolahan hasil perikanan yang tepat guna,memfasilitasi sertifikasi produk hasil perikanan, dan membuat program hilirisasi hasil riset pada skala lapang. Penguatan potensi pasar melalui promosi hasil olahan perikanan budidaya nila, melalui koordinasi antara pemerintah pusat dan daerah untuk membuat program dan kegiatan promosi dalam bentuk pameran di tingkat nasional,membuat pelatihan strategi pemasaran online dan off line untuk meningkatkan pangsa pasar, menguatkan dan merevitalisasi sarana dan prasarana pemasaran, serta membuat dan mengembangkan rumah-rumah promosi untuk produkproduk hasil perikanan pada lokasi strategis. Penguatan kelembagaan produksi, pengolahan dan pemasaran hasil perikanan budidaya nila, melalui pembentukan, pendampingan, pemberdayaan dan penguatan kelembagaan usaha agribisnis perikanan. Resolusi konflik pemanfaatan dan pengelolaan air irigasi untuk kebutuhan pertanian dan perikanan, melalui koordinasi terkait pemanfaatan dan pengelolaan air irigasi, dan membentuk serta menguatkan kelembagaan pengelolaan air irigasi secara bersama menggunakan prinsip-prinsip comanagement.

\section{PERSANTUNAN}

Penelitian ini dibiayai oleh Kementerian Kelautan dan Perikanan melalui anggaran APBN DIPA Pusat Riset Perikanan T.A. 2017. Terima kasih disampaikan kepada Dinas Perikanan Kabupaten Musi Rawas sehingga penelitian ini dapat terlaksana.

\section{DAFTAR PUSTAKA}

Andriyani, R., Hubeis, M.,\& Munandar, A. (2011). Kelayakan dan strategi pengembangan usaha kelompok pembudidauaan ikan melalui program replika skim modal kerja di kelompok tani ikan Mekar Jaya Lido, Bogor. Manajemen IKM, 6(1), 9-19.
Dinas Perikanan Kabupaten Musi Rawas. (2016). Buku Saku Data Perikanan Budidaya Kabupaten Musi Rawas Tahun 2011-2016.

FAO (Food and Agriculture Organization). (2017). Globe Fish - Analysis and information on world fish trade. Diakses dari http://www.fao.org/inaction/globefish/market-reports/resource-detail/ en/c/336945/

Indonesian Legal Brief. (2017a) Peraturan Presiden No. 3 Tahun 2017 tentangRencana Aksi Percepatan Pembangunan Industri Perikanan Nasional. Diakses dari http:// www.hukumonline.com/pusatdata/detail/ It589d2b780a859/node/lt589af723e237d/perpresno-3-tahun-2017-rencana-aksi-percepatanpembangunan-industri-perikanan-nasional.

Indonesian Legal Brief. (2017b). Undang Undang No. 5 Tahun 1984 tentang Perindustrian. Diakses dari http://www.hukumonline.com/pusatdata/detail/327/ node/774/uu-no-5-tahun-1984-perindustrian.

Indonesian Legal Brief. (2017c). Peraturan Menteri Perindustrian Republik Indonesia Nomor 35/MIND/PER/3/2010 tentang Pedoman Teknis Kawasan Industri. Diakses dari http:// www. hukumonline.com/pusatdata/detail/ It4bbecd2f00351/node/314/peraturan-menteriperindustrian-no-35_m-ind_per_3_2010-tahun2010-pedoman-teknis-kawasan-industri.

Kementerian Kelautan dan Perikanan. (2017). Instruksi Presiden No. 7 Tahun 2016 tentang Percepatan Pembangunan Industri Perikanan Nasional.Diakses dari http://infohukum.kkp.go.id/ index.php/hukum/download/1134.

Kurniaty, R.M., Fauzi, A.M.,\& Chozin, M.A. (2012). Daya saing pt benar flora utama berdasarkan aktivitas rantai nilai florikultura. Jurnal Manajemen \& Agribisnis 9(3):146-153.

Muhammad, S. (2011). Kebijakan pembangunan Perikanan dan Kelautan: Pendekatan Sistem. Malang (ID): Universitas Brawijaya Press. p. 263.

Nainggolan, T.Y., Sumantadinata, K.,\& Suryani, A. (2010). Strategi pengembangan usaha "Nila Puff" dalam meningkatkan pendapatan IKM pengolahan hasil perikanan pada CV."X" di Cibinong, Bogor. Manajemen IKM. 5(2), 132-144. 
Nugroho, E., Azwar, Z.I., \& Huwoyon, G.H. (2012). Optimalisasi kapasitas produksi balai benih ikan untuk mendukung industrialisasi ikan nila di Musi Rawas. Puslitbang Perikanan Budidaya. Buku Anjak Perikanan Budidaya, 133-143.

Saragih, B. (2010). Agribisnis: Paradigma baru pembangunan ekonomi berbasis pertanian ( $\mathrm{p}$. 289). PT. Penerbit IPB Press, Bogor.
Sari, S.W., Nurmalina, R., \& Setiawan, B. (2014). Efisiensi kinerja rantai pasok ikan lele di Indramayu, Jawa Barat. Jurnal Manajemen \& Agribisnis, 11(1), 12-23.

Sugiyono. (2009). Memahami penelitian kualitatif. Alfabeta. Bandung.

Zulbainarni, N. (2012). Teori dan praktik pemodelan ekonomi dalam pengelolaan perikanan tangkap. Bogor (ID): IPB Press. 